\title{
Industrial business groups in a context of deindustrialization. The Uruguayan Case, 1980-2015
}

\begin{abstract}
During the 1990s, a series of institutional transformations took place that strongly affected the national productive structure, as well as its agents. Among the main effects of the new openness and liberalization policies are: the loss of relevance of the manufacturing sector in the economy, the abandonment of the complex system of tariffs and subsidies and the accelerated growth of foreign direct investment. How have these transformations impacted the structure of national industrial business groups? This is the central question that guides the article.

The paper takes two samples from large industrial business groups in the late 1980s and in 2015, comparing their evolution in both benchmark years. In the construction of both samples, information was taken from the Central Bank of Uruguay, the Montevideo Stock Exchange, Official Newspaper and press sources, in addition to previous work.

The evidence presented shows that aspects such as size, level of diversification and the form of family control have not varied much in each period. In this sense, the groups have remained stable around certain attributes. On the other hand, there are notable variations in the formation of alliances, the sector distribution of the business portfolio and the links with the government in different modalities.

These variations and permanence can be explained by the impact of the new institutional context in the framework of a small economy like Uruguay. Although similar reforms in other countries in the region have strengthened national business groups (promoting their internationalization and their internal expansion into new business areas), the Uruguayan case seems to represent the opposite. In this way, the paper contributes to the discussion about family groups and their adaptation to the context of the second globalization in peripheral economies.
\end{abstract}

Keywords: Business groups; Liberalization Policies; Institutional Change, Uruguay

Corresponding author: e-mail: juangeymonat@gmail.com

Received 27 September 2019 - Accepted 21 March 2020

This is an Open Access article distributed under the terms of the Creative Commons Attribution-Non-Commercial-No Derivatives License (http://creativecommons.org/licenses/by-nc-nd/4.0/), which permits non-comercial re-use and distribution, provided the original work is properly cited, and is not altered or transformed in any way. 


\section{Introduction}

In the late 1980s, manufacturing activity was a core area in the business portfolio of the main Uruguayan business groups (Stolovich, Rodríguez and Bértola 1987). These groups had consolidated under the framework of the import substitution industrialization model (ISI), which sheltered their businesses in a strongly protected economy (Jacob 1991; Trías 1961). At the end of the $80 \mathrm{~s}, 82 \%$ of the large groups of the national economy participated in the ownership of at least one industrial company.

Economic opening and liberalization policies adopted by the Uruguayan government in the 1990s modified the national productive structure, reducing the importance of the manufacturing. The foreign capital increased its presence, first in the 1990s, then strongly after 2005, displacing national capital in some key economic sectors, including private banking. The transformations that affected the national economy and its agents call for an assessment of the status of national business groups.

As much of the literature has highlighted, business groups are business structures with a high capacity to absorb and adapt to changes in context (Khanna and Yafeh 2007; Leff 1978). The changes in the structure of the groups are largely explained by the implementation of this adaptive capacity (Peres 1998; Barbero 2011; Acosta and Londoño 2003; Colpan and Hikino 2016). The institutional context is, therefore, a decisive variable to understand the future of the structure of business groups and their strategies. But the set of institutions that influence economic performance act on a certain structure and previous trajectory (Greif 2006). The effects of secular market-focused institutions may be dissimilar to national agents in one economy or another. 
The Uruguayan case presented here reinforces this hypothesis. The impact of opening and liberalization policies in the framework of a small economy and with lagging relative productivity, affect the possibilities of insertion of business groups in this new scenario. Changes in economic structure are absorbed as a way to adapt to the new economic environment. Hence, your business portfolio is modified. However, the loss of participation of the groups in some key sectors of the economy (among them the financial system) and the advance of foreign capital in those sectors, have affected the survival capacity of national groups as major players in the business. Unlike other national cases such as Mexico, Chile, Colombia or Brazil, the Uruguayan case shows a negative effect of the structural reforms of the 90s on national business groups (Peres 1998; Hoshino 2010; Jones and Lluch 2011). This uniqueness is part of its appeal when thinking about future comparative studies.

This article is divided in four sections. The second section develops the methodology used to compare the structure of industrial business groups at the end of the 1980s and to the present. The third section aims contextualize the deindustrialization process undergone by the country, the characteristics of foreign direct investment (FDI) and its impacts of them in the structure economy. The fourth section develops the main argument of the study, in terms evolution of the structure of industrial business groups according to six variables: firm size, forms of organization and control, sectoral structure, level of diversification, alliance development, and Governmental linkages. Studies on business groups for the Uruguayan case are almost nonexistent after the $80 \mathrm{~s}^{1}$, so this work and especially this section, constitute an important empirical contribution to national historiography. In the last section the conclusions of the work are

1 The latest systematic general studies on the economy as a whole were coordinated by economist Luis Stolovich (Stolovich, Rodríguez and Bértola 1987; Stolovich 1989, 1994). In recent times, only one study has addressed business groups, but its scope is limited to media groups (Lanza and Buqet 2011). 
presented. There it can be seen that institutional changes have impacted some characteristics of the groups such as the structure of alliances, the sectorial distribution of their businesses, the level of unrelated diversification, and their income-obtaining strategy based on political linkages. However, other characteristics are maintained, such as the average size and the way of organization and control.

\section{Methodology}

The methodological strategy of this study is based on the comparison of industrial business groups in two periods: the late 1980s and from 2010 to 2015. We take as a business group the well-known definition of Khanna and Yafeh (2007).

Different sources were taken into account for both periods to construct the business groups. For the late 1980s, we mainly used information from Stolovich, Rodríguez and Bértola (1987), which included data for 1985, in some cases complemented with data from Stolovich (1989, 1993).

For the recent period, we used as initial source data published by the Central Bank of Uruguay (BCU) in the Central Credit Risk Registry. To complement this information, research was conducted taking into account sources such as the press, company websites, Montevideo Stock Exchange reports, Official Gazette publications and National Registry of Commerce data, as well as information provided by qualified informants linked to the business world ${ }^{2}$.

To make the information comparable, we started by identifying a set of 120 large industrial companies for each point, stratifying them based on sales. Different sources were used to construct both rankings. For the late 1980s, a study by Stolovich and Rodríguez (1988) was

2 See Geymonat (2019) for a thorough explanation about the methodological process used to construct the 2015 business groups. 
used. From this work, we used the data presented by the mentioned authors for the year 1987, disaggregating industrial companies from all the rest.

For the second period, we used the microdata from 2010 Annual Economic Activity Survey (EAAE), provided by the National Statistics Institute (INE), and selected companies whose main activity was classified as part of the Manufacturing Industry Division. After stratifying the set of the main 120 companies according to sales, we proceeded to identify them because the microdata is anonymous. To this goal, we did crosstab data from the Permanent Register of Business Activity, also published by INE, and from Customs export data. Based on both rankings, we identified the integration of large companies into larger structures, such as business groups or transnational companies.

Thus, we established two samples of industrial business groups. For the 1985-1989 period, the 120 most important companies in the industry had links to 80 national groups, while in 20102015 the industrial upper tier was linked to 58 groups. The decrease in the number of groups is largely explained by the increase in foreign capital in industrial company control, as discussed below.

\section{Uruguayan deindustrialization}

The 1980s reflected a period of crisis of the industrializing model in Uruguay, after a pronounced stagnation dating back to the $1950 \mathrm{~s}$, then were exercised some attempts to reorient the sector to export during the 1970s (Notaro 1985; Astori 1989). The beginning of this decline in the industry is showed in Figure 1. The proportion of industry in the Gross Domestic Product varies depending of current or constant currency. Although, in any case, it is clear that it was during the 1990s where the greatest decrease was made. 
Figure 1. Proportion of the manufacturing industry in GDP at current and constant prices $(1970=100)$

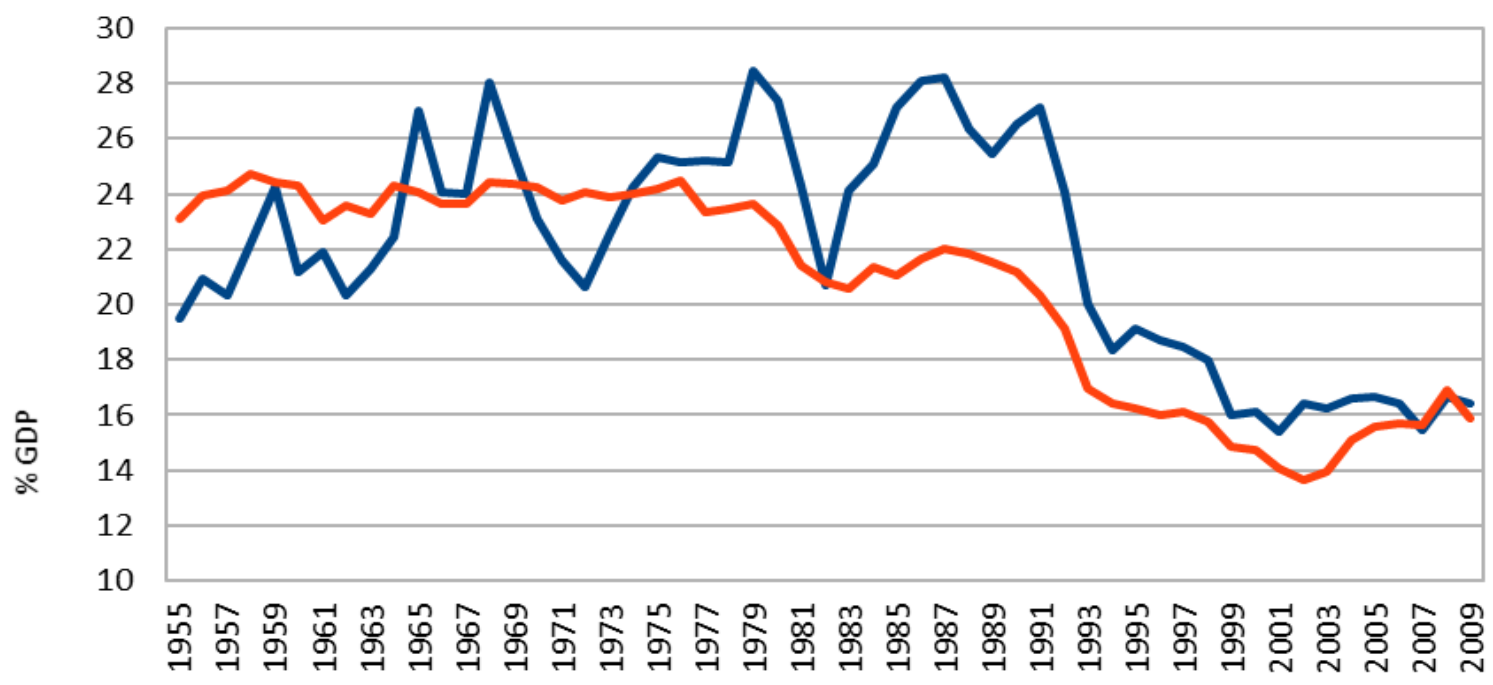

-Manufactures/GDP (current prices) —Manufactures/GDP (constant prices 1970)

Source: Banco Central de Uruguay (BCU) y Montevideo Oxford Latin American Economic History Database (Moxlad).

A series of liberalization and economic opening policies were established during this decade, resulting a net negative effect on the industrial sector that according to Rama (1990), Olesker (2001) and Finch (2005) depended to a great extent, on protectionist policies. The number of companies and the number of employees decreased during this decade. At the same time, and despite the fact that the industrial product remained stagnant, productivity grew because of a technological modernization process and elimination of lagging signatures.

Table 1. Variation of companies, employees and industry performance 1988-1997

\begin{tabular}{|c|c|}
\hline & $\begin{array}{c}\text { Variation 1988-1997 } \\
\text { (\%) }\end{array}$ \\
\hline Total industrial companies & -42.3 \\
\hline Companies with more than 5 employees & -33.2 \\
\hline Labor productivity & 84.5 \\
\hline Staff employed & -42.9 \\
\hline Physical volume & 1.7 \\
\hline
\end{tabular}

Source: III y IV Censo Económico. Instituto Nacional de Estadística (INE). 
The economic model established in the 1990s pushed to a deep economic crisis in Uruguay until 2002. From 2005 onwards there was a modification in the political scenario after the electoral triumph of a left-wing political coalition (named "Frente Amplio"). At the same time, the external conditions impacting clearly in Uruguay because the increase of prices of raw materials exported, which translated into important GDP growth rates -the most important of the country's economic history. The recovery that followed Uruguay after 2002 led to sustained industrial growth, although similar to the growth of the total economy. Therefore, the industrial sector continued to represent a portion of GDP similar to that of the previous decade. The distinctive features in terms of industrial policies of the $1990 \mathrm{~s}$ were maintained and consolidated. Economic opening increased and domestic prices adjustment policies were not deployed. The market remained as the allocator of resources, and the industrial structure continued its course based on agribusinesses. The sectors linked to the primary sector presented comparative advantages and were able to remain successful and in expanding, while those focused on labor-intensive processes or linked to the domestic market declined. A group of "non-traditional" branch sectors should have an outstanding performance, protected -to a large extent- by regional and commercial integration based on trade agreements, such as Mercosur ${ }^{3}$. Some of these manufacturing sectors were synthetic rubber, plastics, basic chemicals or pharmaceuticals.

\footnotetext{
3 The Southern Common Market (Mercosur) is a regional integration treaty signed in 1994 by Argentina, Brazil, Paraguay and Uruguay. Among the agreements was the fixing of common tariffs, and the progressive reduction of tariffs for most of the products marketed among the bloc's member countries.
} 
Figure 2. Industrial structure in percentage of manufacturing product 1978-2015

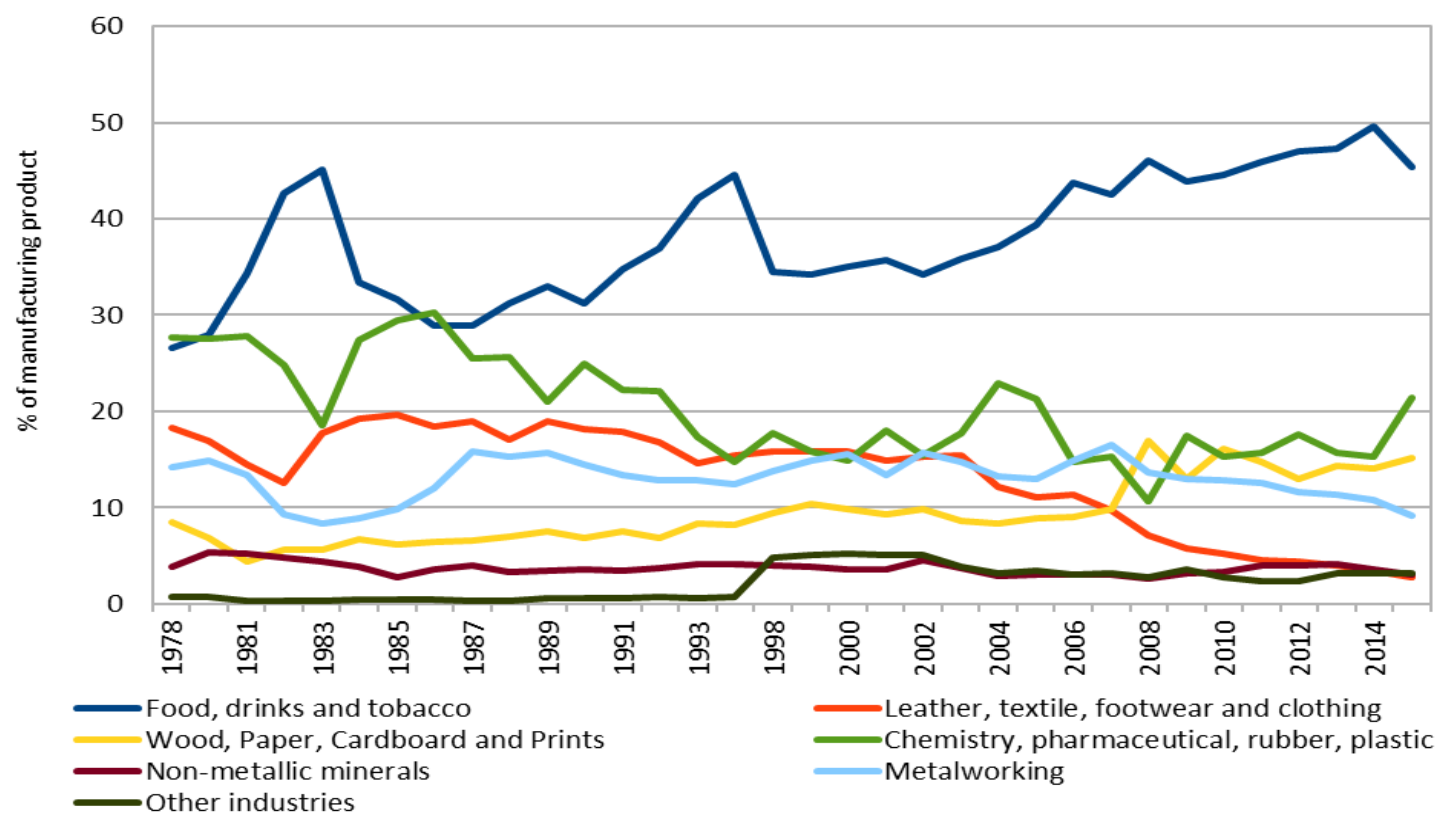

Source: Own elaboration based on Encuesta industrial del Actividad (EIA), Encuesta Anual de Actividad Económica (EAAE) y Banco Central del Uruguay (BCU).

Table 2. Manufacturing product in Uruguay, according to the main type of input used and the export level (1985-2010)

\begin{tabular}{|c|c|c|c|c|c|c|c|}
\hline \multicolumn{4}{|l|}{1985} & \multicolumn{4}{|l|}{2010} \\
\hline & $\begin{array}{c}\text { Non } \\
\text { exporter }\end{array}$ & $\begin{array}{c}\text { Moderately } \\
\text { exporter }\end{array}$ & $\begin{array}{l}\text { Strongly } \\
\text { exporter }\end{array}$ & & $\begin{array}{c}\text { Non } \\
\text { exporter }\end{array}$ & $\begin{array}{c}\text { Moderately } \\
\text { exporter }\end{array}$ & $\begin{array}{l}\text { Strongly } \\
\text { exporter }\end{array}$ \\
\hline $\begin{array}{l}\text { National } \\
\text { Primary } \\
\text { Inputs (\%) }\end{array}$ & 3.5 & 4.4 & 17,3 & $\begin{array}{l}\text { National } \\
\text { Primary } \\
\text { Inputs }\end{array}$ & 1.6 & 0.8 & 33.9 \\
\hline $\begin{array}{l}\text { National } \\
\text { Industrial } \\
\text { Inputs (\%) }\end{array}$ & 13.0 & 5.2 & 6.7 & $\begin{array}{l}\text { National } \\
\text { Industrial } \\
\text { Inputs }\end{array}$ & 17.5 & 8.8 & 9.2 \\
\hline $\begin{array}{l}\text { Imported } \\
\text { Imputs (\%) }\end{array}$ & 29.7 & 12.3 & 0.0 & $\begin{array}{l}\text { Imported } \\
\text { Imputs }\end{array}$ & 3.9 & 21.0 & 3.3 \\
\hline
\end{tabular}

Source: Bértola and Bittencourt (2013)

Note: for 1985 a set of branches equivalent to $7.9 \%$ of the manufacturing product were not classified.

The transformations in the size of the industrial sector and average unit size led to increased sectorial concentration. Measured as the ratio between the sales of the 100 largest companies and total industrial sales, this level went from $0.55 \%$ in 1986 according to Buxedas (1992) to $0.68 \%$ in 2010 . Most importantly, and especially after 2005, there was a sharp expansion of 
foreign capital in the sector, in line with an increased FDI over the national economy as a whole. Between 2006 and 2016, the average annual FDI, as proportion of GDP, was around 4.6\%, with a strong growth of capital from the region (mainly Brazil and Argentina). This number is quite high, considering that in 1970-2000 the same ratio was $0.6 \%$ (Reig 2013). An analysis of the 120 main industrial companies in 1987 and 2010 will reveal that this sector was no exception (see Table 3).

Table 3. Property of the 120 main manufacturing companies

\begin{tabular}{|c|c|c|c|c|}
\hline & National & Foreing & $\begin{array}{c}\text { Associated } \\
\text { (national and foreing) }\end{array}$ & Total \\
\hline $\mathbf{1 9 8 7}$ & 20 & 16 & 84 & 120 \\
\hline $\mathbf{2 0 1 0}$ & 50 & 12 & 58 & 120 \\
\hline
\end{tabular}

Source: Own elaboration based on EAAE 2010 microdata, Stolovich and Rodríguez (1988), press sources and qualified informants.

As suggested Shaick (2006), foreign capital would tend to be a modernizing agent, operating with greater technological endowment, and presenting higher levels of productivity in a country. This, and its presence in sectors having comparative advantages could explain its high level of participation in the operating surplus, suggesting that large foreign industrial companies have high levels of profitability compared to domestic ones (see Table 4).

Table 4. Participation on different variables of the main 120 industrial companies according to origin of capital (in \%)

\begin{tabular}{|l|c|c|}
\hline & Foreing (and associated) & National \\
\hline Output value of production & 49.01 & 50.99 \\
\hline Gross value added & 52.03 & 47.97 \\
\hline Staff employed & 48.62 & 51.38 \\
\hline Capital stock & 62.28 & 37.72 \\
\hline Operating surplus & 67.84 & 32.16 \\
\hline
\end{tabular}

Source: Own elaboration based on EAAE 2010 microdata.

An increased foreign influence would tend to displace domestic capital from some branches of the economy. This is confirmed by the recent performance of national economy, because of 
$100 \%$ of private banking is owned by foreigners and more than $70 \%$ of exports are carried out by these companies.

\section{Changes in the structure of domestic industrial business groups}

It is possible to assume that Uruguayan groups have undergone significant changes in their structure in the face of events such as the loss of relative importance of industry, its own structural transformation, and the new flow of FDI. In this section, we propose to analyze this issue based on some variables that have been highlighted by the literature (Colpan, Hikino and Lincoln 2010; Khanna and Yafeh 2007; Granovetter 2005) and for which we have been able to compile data.

\subsection{Family control and horizontal organization}

When we approach to main business groups in Uruguay during the years selected, we found that most correspond to family groups. To define a group as a family group, we considered the participation of more than one family member (by blood or marriage) in the boards of the companies and/or the existence of inheritance mechanisms and generational transferences in their history ${ }^{4}$.

Based on this, we identified in 2015 that 45 were family groups from 58 total groups. From total of 13 , two clearly were cases of non-family groups, and 11 did not presented a clear family imprint. In some of those cases the groups were controlled by a single entrepreneur but not by another member of his family. It makes impossible to identify in a specific way the factor (or factors) behind the replacement or alternance of the leader or the intergenerational continuity.

4 A similar criterion was adopted by Almaraz and Ramírez (2018), and by Fernández and Lluch (2015), when referring to business families. 
It is likely that some of these seemingly non-family groups are actually family groups. Therefore, it is also likely that the relative imprint of family groups is underestimated. Outstanding to this lack of information, the percentage of family groups in the late 1980s could vary between $77 \%$ and $90 \%$ of total groups that were identified. Both in the 1980 s and nowadays, the family structure of most groups follows a single-lineage, nuclear family pattern. There are few cases where one or more nuclear families are combined with other relatives constituting extend family business or composed family business as explained by Almaraz $(2018,82)$.

Another characteristic of these industrial groups is their horizontal organization. The organization of national groups is more similar to a loose network form, where there is no control over a group entities by a set of parental or differentiated companies, we found that unicity and coordination is based on direct participation by family members in different firms that making up the group (Jones and Colpan 2010, 84-85). This form of organization has been a constant throughout the history of national groups, with few exceptions. From 111 groups studied by Stolovich, Rodríguez and Bértola (1987), only one of them displayed a pyramidal structure with a holding company (hard core) participating in the other entities. By 2015, this type of structure was visible in a single group, although it was not a family group.

\subsection{Size}

Another important variant is the size of the groups, here we consider the number of connected companies that can be an approximate measure to understand the structure size, before to analyze the economic power of each group. Although in some cases the number of controlled companies and the magnitude of controlled capital matches, this is not a rule. Table 5 shows for 1985 and 2015 the national industrial groups according to the average size related to the 
number of companies controlled. Differences founded suggest us that an upward reading over the period. However, it is likely the number of connected companies in the 1985 groups was underestimated. Mainly, because of the way in which agricultural firms ${ }^{5}$ are accounted for. Therefore, it can be concluded that average group size has not changed substantially during the period studied.

Table 5. Size of national business groups in number of companies in Uruguay (1985-2015)

\begin{tabular}{|l|r|r|}
\hline & $\mathbf{1 9 8 5}$ & $\mathbf{2 0 1 5}$ \\
\hline Mean & 6.8 & 7.5 \\
\hline Median & 6 & 6 \\
\hline Maximum & 26 & 36 \\
\hline Minimum & 2 & 2 \\
\hline 1st quartile & 3 & 4 \\
\hline 3rd quartile & 8 & 9 \\
\hline Total of groups over the 120 most important companies & 80 & 58 \\
\hline
\end{tabular}

Source: Own elaboration based on Stolovich, Rodríguez and Bértola (1987) and Geymonat (2019).

This data is still striking. It gives an account of a structure that, in general terms, has not advanced in its complexity. It is even possible to notice that their size does not seem to have changed strongly in at least sixty years. From a sample of 20 industrial groups, reconstructed based on the data extracted from a work by Trías (1961) for the 1950s, we can observe similar values: an average of 7.8, a minimum value of 2 and a maximum of 21 for the set of cases taken. This stagnation in size may be part of the explanation of the low variability in the forms of organization and control of national groups (see section 4.1). As there is no growth in productive units and business diversification (see section 4.3), the incentives to advance in more complex organizational forms do not exist.

5 Stolovich, Rodríguez and Bértola (1987) includes several references to land tenure, without specifying the number of firms. In our study, we identified agricultural firms by company name. 
What elements explain this stagnation in the size of national industrial groups? A first guess has to do with the size of the national economy. It is small, with a reduced domestic market (3,300,000 inhabitants in 2015). This aspect affects the scale of the firms and with it the possibilities of accumulating capital and expanding to other sectors and / or regions.

Another aspect that affects the size of the groups has to do with reforms in the economic institutions during the 1990s. This set of reforms has opened the national economy to competition of imported goods, as well as inflow of foreign capital. In different ways, this new scenario generates several incentives for the specialization of activities. In the first place, the economic opening allows the export development of some sectors, removing the restrictions to the growth of the size of the internal market. This means that accumulating capital and growth can be achieved in the same sector, and not only through expansion into other activities. On the other hand, the possibility of importing inputs without restrictions reduces the need for firms to create subsidiaries to produce these items. Finally, in a scenario of total foreign control of the national private banking sector, part of the possibilities of obtaining capital for the groups consists of selling assets and companies. This situation has meant that several groups reduce their number of companies by concentrating capital in those with greater possibilities of development.

Unlike other countries in the region, in Uruguay the period of opening and liberalization did not advance in the privatization of public companies. Therefore, there were no opportunities for business in these areas either. At the same time, national companies were not large enough to launch themselves into conquering regional markets and becoming trans-Latin American, a phenomenon that did occur in countries such as Chile, Mexico and Brazil. 


\subsection{Diversification patterns}

The integration of related activities is follows different strategies, either horizontally (when companies are controlled in the same productive or commercial phase) or vertically (when different links in the same value chain are integrated). The first kind of related integration tends to follow an expansion strategy for dominating the same market. Vertical integration responds to other specific needs. This kind of diversification may be aimed at controlling certain strategic stages of the business, either because they are concentrated links, with the possibility of setting prices backward or forward, or simply because they imply a higher turnover. Controlling strategic inputs, or those that have a certain specificity, appears to be another reason for groups to diversify vertically (Chandler 1987; Hopkings and Wallerstein 1994; Williamson 1985).

Table 6. Business groups in Uruguay, with unrelated diversification in 1985 and 2015

\begin{tabular}{|l|r|r|}
\hline & 1985 & 2015 \\
\hline Diversified groups in more than one value chain & 39 & 32 \\
\hline Total analyzed (\%) & 55 & 55 \\
\hline Average value chains of groups with unrelated diversification & 3.3 & 2.8 \\
\hline Median value chains of groups with unrelated diversification & 3 & 2 \\
\hline
\end{tabular}

Source: Own elaboration based on Stolovich, Rodríguez and Bértola (1987) and Geymonat (2019).

However, horizontal and vertical movements in the same value chain are not the only form of diversification. We will use the term unrelated diversification when referring to the coexistence of activities that are not technically or commercially related to each other. This type of diversification responds to other needs, also highlighted in the literature on business groups, resulting from institutional uncertainty, economic cycle variability, or the use of know-how acquired in previous activities, among other factors (Colpan, Hikino and Lincoln 2010; Khanna and Yafeh 2007; Barbero 2011). The uncertainty that characterizes peripheral economies, and 
especially growth cyclicality and volatility, could explain this kind of expansion toward unrelated activities tending to diversify risks.

The percentage of diversified groups in unrelated activities was stable over the period as show in Table 6. What seems to be decreasing, however, is the number of activities in which they diversify. This is consistent with what is expected in terms of the overall economic performance. In the 1980s, the Uruguayan economy was not characterized by an expansive phase of the economic cycle. Quite the opposite. The way in which individual capital expanded consisted largely in diversifying into other activities. At the same time, diversifying activities was a way of diversifying risk. The country's economic structure had been accumulating a set of tensions and contradictions resulting from its protected industrial structure and its productive backwardness. This set of contradictions foretold a change in economic policy, sooner or later. It is important to visualize this aspect as part of the incentive structure in place for industrial entrepreneurs at the time. In addition to volatility, there was the perception that the activity that was being increasingly questioned, and that without support its chances of success were uncertain.

The 1990s were a turbulent decade when it came to changes in economic structure and the rules of the economic game within the national and regional space, leading to a new set of incentives. Maintaining a lagging industry was no longer a priority and the commercial and "technological update" was perceived as a prerequisite to continue operating in some sectors. It was also evident that several branches would have great difficulties in processing these transformations. In this context, it is likely that the existing business groups preferred to focus on their most profitable operations, liquidating those lagging behind or with fewer chances to integrate in the 
new context. In parallel, the service sector began a relative expansion and diversification phase, offering attractive business opportunities.

In this century, the arrival of large flows of FDI to the country encouraged asset sales that capitalized some national groups, especially those highly indebted to the financial system. This mechanism reinforced the existing trend to reduce unrelated diversification, promoting specialization in activities that began to show greater development prospects. Similarly, groups created and/or "emerging" in 2004-2015 did not benefit from strong incentives for unrelated diversification. Economic growth in the last decade may have allowed for constant surplus reinvestment in the same activity or value chain.

\subsection{Alliance structure}

By alliance we understand the convergence of different groups and/or businessmen in the control a company. An analysis of the tendency of national groups to make alliances among themselves or with other national entrepreneurs - either inside or outside the industry- reveals a decrease in this strategy at both the relative and absolute levels. This trend seems to be in line with the specialization process described above, where groups tend to concentrate in fewer activities.

Table 7. Alliance structure of national groups in Uruguay, 1985-2015

\begin{tabular}{|l|c|c|}
\hline Alliance structure of national groups & 1985 & 2015 \\
\hline $\begin{array}{l}\text { Groups maintaining alliances with other national groups or } \\
\text { entrepreneurs (\%) }\end{array}$ & 67 & 46 \\
\hline Groups maintaining alliances with foreign companies (\%) & 35 & 32 \\
\hline
\end{tabular}

Source: Own elaboration based on Stolovich, Rodríguez and Bértola (1987) and Geymonat (2019).

We identified three types of alliances according to their motivation. The first motivation for an alliance between different groups can respond to the need to reach (improve) the size that can be a necessary condition to operate in certain branches and upgrading. Another motivation to 
seek alliances between groups can be more natural because responds to the existence of common strategic linkages as part of chains of production or distribution. This situation enables and sustains alliances around the control of certain inputs, secondary services connected to the main activity and access to credit. As we can see further, there are groups that combine both aspects.

The development of more secular economic institutions would result in lower transaction costs, and thus in fewer incentives for developing alliances to controlling of the chains production and distribution but is not the case to the alliances to scale. This element should be more complex with the effect of the structural reforms adopted in the 1990s that affected the links of internal economy (Hirschman 1983). The possibility to obtaining imported inputs and services can produce productive delocalization processes and can affect the possibility of deploying the alliances to control chains. An analysis of the main motivations for group alliances seems to corroborate this hypothesis as showed in Table 8 if we consider the importance of FDI is the las period. The underlying needs for alliances development for controlling strategic inputs and services have diminished.

Table 8. Reasons that support alliances between national groups in Uruguay, 1985 and 2015

\begin{tabular}{|l|c|c|c|c|}
\hline Reasons that support alliances & $\mathbf{1 9 8 5}$ & $\mathbf{1 9 8 5}(\boldsymbol{\%})$ & $\mathbf{2 0 1 5}$ & $\mathbf{2 0 1 5}(\boldsymbol{\%})$ \\
\hline Scale & 22 & 50 & 17 & 63 \\
\hline Control of related activities & 6 & 14 & 2 & 7 \\
\hline Both & 16 & 36 & 8 & 30 \\
\hline Total & 44 & 100 & 27 & 100 \\
\hline
\end{tabular}

Source: Own elaboration based on Stolovich, Rodríguez and Bértola (1987) and Geymonat (2019).

Nevertheless, the national alliances with foreigners were relatively stable over the period as showed Table 7. In 1985, 35\% of the industrial groups in Uruguay sharing the control with foreign companies. In 2015 this pathway was very similar (32\%). The structural motivation that drives national capitals to seek this type of alliance is not very different from that which 
supports the search for alliances between national capitals. The emphasis here is distributed between the possibility of capitalizing companies by adding a foreign partner, and the possibility of establishing alliances with capitals that provide technology or strategic inputs, or which have potential for market expansion (Stolovich, 1989).

So far, we outlined some hypotheses regarding to the needs of driving national capital to seek an association with foreign capital in a context of high level of FDI. We should then ask the following question about the other side of the equation: Why would foreign capital be interested in partnering with a domestic counterpart? A possible answer can include several elements. First, in the context of a closed economy and a more incipient development of information and communication systems, and the weakness of global institutions to norm the FDI, the alliances with domestic capitals becomes an asset to deal with the local institutional framework. In one hand, the domestic groups, strong in the local economy and with a good portfolio of political connections, would act as an agent to reduce the transaction costs in a market characterized or marred with imperfections. On the other hand, minimizing costs or making economies of scale in face to common needs could be a motivation for the alliances with domestic actors in a stock of subsidiary and/or complementary activities linked to a core activity which is developed by foreign capitals.

The paradox is that market imperfections were reduced, and the secular development of economic institutions were enhanced, the local agents should lose their advantage and their possibilities of internalizing key aspects to make alliances to begin their own growth. This seems to be the case if we analyze the alliances between foreign and domestic capitals in the industrial sector in both periods of our study. Considering exclusively the point of view of foreigners the results are showing in the Table 9. 
Table 9. Foreign capital in alliances with Uruguayan capitals, 1985 and 2015

\begin{tabular}{|l|r|r|}
\hline $\begin{array}{l}\text { A.- Foreign capitals maintaining alliances with domestic groups in } \\
\text { large industrial companies }\end{array}$ & 1985 & \multicolumn{1}{|c|}{2015} \\
\hline B.-Total foreign capital in large industrial companies & 29 & 14 \\
\hline Alliances as \% (A/B) & 62.1 & 30.4 \\
\hline
\end{tabular}

Source: Prepared by the author based on Stolovich (1989), EAAE 2010, press sources, company websites and qualified informants.

The opening and liberalization of trade and financial flows in Uruguay also promoted a growing institutional convergence with other countries in the region and around the world too. In this way, it would have resulted in a sort of secularization of economic institutions, reducing the efficiency of behaviors based on personal power and on direct access to incumbent administrations. In the other, an improvement in the supply of technical teams, capable of performing efficiently in local level, would be a perfect replacement for economic and political power as a supporter to move through the domestic institutional environment. In addition, currently a large share of foreign investment comes from within the region. As these entrepreneurs have deployed significant capacities to operate in volatile and uncertain contexts, the need for a local guide tends to become irrelevant. All these elements could have contributed to reduce the incentives to establish new alliances by foreign capital.

\subsection{Sectoral composition of industrial groups}

Regarding to sectoral composition of industrial groups in Uruguay, the first aspect to highlight is the decline of manufacturing in business portfolios since 1985 until now. This can be appreciated by comparing some central position measures with respect to the number of industrial firms over the total of companies in each group. As we pointed out when we referred to group size, agricultural firms are likely to be underestimated in the 1985 data. To ensure a 
more accurate the interpretation, for 2015 we included industrial participation data and excluded the agricultural firms.

Table 10. Industrialization level (industrial companies / total companies of each group)

\begin{tabular}{|l|c|c|c|}
\hline Average of the relative sharing of the industry in the groups & $\mathbf{1 9 8 5}$ & $\mathbf{2 0 1 5}$ & $\mathbf{2 0 1 5}$ \\
\hline Median of the relative sharing of the industry in the groups & 0.57 & 0.35 & 0.44 \\
\hline
\end{tabular}

* no groups with rural businesses

Source: Own elaboration based on Stolovich, Rodríguez and Bértola (1987) and Geymonat (2019).

Even after removing the predisposition that can be the difference in the accounting of agricultural firms, it clear that in 2015 industrial groups are less than those of the 1980s decade. In the one hand, the groups can follow the general behavior of the economic structure, when the manufacturing sector has declined, they had too, but they don't dissolve their structure. On the other, we can see that growth of industrial groups with investments in agricultural activities has increased. The large margins of cases without data complicate a full conclusion in this regard. However, assuming that in both periods the set of cases the tendency is distributed equally, showing that groups combined relative sharing in the industrial and agricultural sectors to increase as we can see in Table 11.

Table 11. Industrial groups with at least one agricultural company in Uruguay, 1985 and 2015

\begin{tabular}{|l|c|c|}
\hline & $\begin{array}{c}\mathbf{1 9 8 5} \\
(\boldsymbol{\%})\end{array}$ & $\begin{array}{c}\mathbf{2 0 1 5} \\
(\boldsymbol{\%})\end{array}$ \\
\hline With agricultural companies (at least one) & 50.0 & 60.4 \\
\hline Without agricultural companies & 28.8 & 15.5 \\
\hline Cases without data & 21.2 & 24.1 \\
\hline Total & 100.0 & 100.0 \\
\hline
\end{tabular}

Source: Own elaboration based on Stolovich, Rodríguez and Bértola (1987) and Geymonat (2019).

To a large extent, this increase may be associated with two phenomena. First, to diversification towards primary activities that became increasingly important during the period of study, and which always is represented as the country's "safe" productive advantages. Against the 
backdrop of a major branch transformations and the growing of uncertainties in this regard, the strategy to maintain or invest in primary activities may have been sensible because the country has historically depended on them. Secondly, investment in "land" is often used as a kind of financial asset, and a haven for accumulating capital.

Finally, is particularly important remarks that industrial groups and national business groups in general departure the national financial system. This divorce is associated to a deeply rooted process. Since the 1960s, the number of business groups linked to bank ownership had been declining (Stolovich, Rodríguez and Bértola 1987). In 1980, 22\% of the groups studied participated in the ownership of a bank. After the 2002 crisis, all private banking sold their assets to foreign investors. The loss of relevance of business groups in the financial system it left them in a position of vulnerability and subordination with respect to foreign private banks and public banking. ${ }^{6}$

As banking became entirely foreign owned in last ten years, the financing strategies of the national groups has been upended. For this additional reason the groups investing in "safe" assets, such as land or another type of Real Estate. At the same way, they have opting to sell part of their companies to foreigners as a quick via to recapitalize them and to obtain cash. Both ways became important to the subsistence of groups.

\subsection{Governmental connections}

Large national groups have maintained close ties with the political system. During the emergence and expansion of ISI, large company owners and business organizations were integrated into the management of several key government entities, such as public banking, or

6 Other mechanisms, such as the Montevideo Stock Exchange, have not played a dynamic role in the capital market. 
the Export and Import Commission ${ }^{7}$. Business groups were able to co-opt some of the economic engineering of the time (for example, setting tariffs or multiple exchange rates), using it as a mechanism to obtain particular benefits (Zurbriggen 2006). Although this type of participation changed over time (Trías 1961, 1971; Stolovich and Rodríguez 1987), business groups have maintained their presence in the arena of politic and they still closing to Government control. Until the 1980s, entrepreneurs influencing specific policies through individual or collective lobbying. The most prominent example was the increase of effective tariff protection (Rama 1990). However, given the economic opening and liberalization policies in which the country had been boarded, this mechanism disappeared as a general strategy. The Government had to establish clear rules and face the necessity of social cost to enforce them, under the condition that institutions would act on growth and development processes. This is the scenario that should be interpreted of how the reforms passed by the National Party in the 1990s. During the process of correspondent administration, in any case, members of the economic power were government officials (Stolovich and Rodríguez 1987).

After 2005, during the center-left government administrations, the proportion of representatives from big national capital have been largely reduced in occupy government seats. This apparent development conceals a larger and possibly a more persistent phenomena, which is related to the different kinds of relationships between economic powerful and Government. They have evolved from an attempt to use the State as part of an income strategy to an increasingly impersonal rapport, based on general common rules, and with a lower level of particularization (Viñales 2019). The possibility of generating isolated particular conditions (specific tariffs,

7 Export and import control were entrusted to a Government regulatory entity that included to national businessmen. Its fundamental mandate consisted in controlling currency flow and setting import sectoral volumes, as well as preferential exchange rates (García Repetto 2017). 
subsidies, etc.) is detrimental to the institutional sense of the model. Business lobbying as a practice is now very limited; it does not go away but is reduced in the face of a more general and impersonal system. It is clear that part of the economic promotion legislation and instruments grant specific benefits to companies. An example of this is the Investment Promotion Act, ${ }^{8}$ but the access mechanism to this kind of benefits is standardized, and its successive reforms have tended to reduce -although not always effectively-its biases.

\section{Conclusions}

This paper provides evidence on a subject that has been marginally addressed by Uruguayan economic history. Although its main contribution is descriptive, part of this dynamic description requires explaining its variation. In this sense, in this paper we have introduced some attempted explanations, which remain hypotheses for future research.

During the period under study, national business groups constitute a structure with broad capacities to mitigate adverse and volatile context effects. A proof of this seems to be its business portfolio reconversion to the tune of the change undergone by the general economic structure. Internally, industrial business groups are less industrial than in the 1980s, concentrating a good part of their business in other sectors. Their agrarian base -land portfolios investments and agricultural activities- seems to have increased during the period, also in line with context incentives.

In general terms, during the period business groups tended to concentrate control and ownership of their companies, doing away with alliances, to a large extent. On the other hand, in companies where the confluence of several groups in control or ownership is maintained, the motivation

8 An instrument granting tax exemptions to investing companies. 
of this alliance also changes. The need to reach specific levels of capital accumulation to operate at a certain productive scale in one sector displaces other motivations, such as the need to control strategic inputs and services. A new institutional and technical context, which brought about a reduction in transaction costs, operates as a disincentive to this type of internalization. Given their dwindling presence in the financial system, and in a context of pronounced economic growth (for the historical characteristics of Uruguayan economy), business groups have tended to specialize their activities in fewer value chains than during the 1980 s. The possibility of recycling surpluses while getting rid of lagging businesses, as well as the sale of some companies to foreign capital as a source of liquidity, is part of the explanation for this phenomenon.

But the groups have also maintained some structural aspects, including their average size and their forms of organization and control. These aspects can also be explained by determinations of the institutional context. The stagnation in the growth of the groups is due to the scale limitations of the Uruguayan economy, as well as to the difficulties that national entrepreneurs have encountered in the framework of an economic opening process. The inflow of foreign capital into key sectors of the economy has deepened this backwardness of the national ones.

In this framework, there are no real needs for groups to adopt more complex forms of organization. Horizontality continues to be a characteristic of these groups, as does family control. 


\section{References}

Acosta, Nora, and Carlos Londoño. 2003. Grupo Empresarial Antioqueño: evolución de políticas y estrategias, 1978-2002. Vol. 74 of Monografías Universidad de los Andes. Bogotá: Universidad de los Andes.

Almaraz, Araceli. 2018. "La empresa familiar y las familias empresariales en México: una propuesta teórica." In Familias empresariales en México. Sucesión generacional y continuidad en el siglo $X X$, edited by Araceli Almaraz and Luis Alfonso Ramirez, 57-93. Tijuana: El Colegio de la Frontera Norte.

Almaraz, Araceli, and Luis Alfonso Ramirez, eds. 2018. Familias empresariales en México. Sucesión generacional y continuidad en el siglo XX. Tijuana: El Colegio de la Frontera Norte.

Barbero, María Inés. 2011. "Los grupos económicos en la Argentina en una perspectiva de largo plazo (siglos XIX y XX)". In El impacto histórico de la globalización en Argentina y Chile: empresas y empresarios, edited by Geoffrey Jones and Andrea Lluch, 1-37. Buenos Aires: Temas.

Bértola, Luís, and Gustavo Bittencourt. 2013. Un balance histórico de la industria uruguaya: entre el “destino manifiesto" y el voluntarismo. Montevideo: Ministerio de Industria Energía y Minería. Universidad de la República.

Buxedas, Martín. 1992. Oligopolios y dinámica industrial. El caso de Uruguay. Montevideo: Ciedur.

Chandler, Alfred. 1987. La mano visible. La revolución en la dirección de la empresa norteamericana. Madrid: Centro de Publicaciones del Ministerio de Trabajo y Seguridad Social de España.

Colpan, Asli, Takashi Hikino and James Lincoln, eds. 2010. Oxford Handbook of Business Groups. Oxford: Oxford Univiersity Press.

Colpan, Asli, and Takashi Hikino. 2016. "The Evolutionary Dynamics of Diversified Business Groups in the West. History and Theory". In Business Groups in the West: Origins, Evolution, and Resilience, edited by Asli Colpan and Takashi Hikino, 26-69. Oxford: Oxford University Press

Fernández Paloma, and Andrea Lluch, eds. 2015. Familias empresarias y grandes empresas familiares en América Latina y España: Una visión de largo plazo. Bilbao: Fundación BBVA.

Finch, Henry. 2005. La economía política del Uruguay contemporáneo 1870-2000. Montevideo: Ediciones de la Banda Oriental.

García Repetto, Ulises. 2017. "El Contralor de Exportaciones e Importaciones en Uruguay (1941-1959)" Documento de Trabajo 13/17 Instituto de Economía. Montevideo: Facultad de Ciencias Económicas y de la Administración-Universidad de la República. 
Geymonat, Juan. 2019. "Grupos económicos nacionales con presencia en la industria (2010-2015)" Documento de Trabajo $N^{\circ} 55$ Programa de historia Económica y Social. Montevideo: Facultad de Ciencias Sociales- Universidad de la República.

Greif, Avner. 2006. Institutions and the path to the modern economy. New York: Cambridge University Press.

Hirschman, Albert Otto. 1983. "La estrategia del desarrollo económico.” El Trimestre Económico 50:1331-1424.

Hopkings, Terence, and Immanuel Wallerstein. 1994. "Commodity Chains in the Capitalist WorldEconomy Prior to 1800". In Commodity chains and global capitalism, edited by G. Gereffi and M. Korzeniewicz, 17-20. Westport: Praeger Publishers.

Hoshino, Taeko. 2010. "Business groups in México". In Oxford Handbook of Business Groups, edited by Colpan, Asli; Takashi Hikino and James Lincoln. Oxford: Oxford University Press.

Jacob, Raúl. 1991. Las otras dinastías. 1915-1945. Montevideo: Edición Proyección.

Jones, Geoffrey, and Aslim Colpan. 2010. "Business groups in historical perspectives." In Oxford Handbook of Business Groups, edited by Aslim Colpan, Takashi Hikino and James Lincoln. Oxford: Oxford University Press.

Jones, Geoffrey, and Andrea Lluch, eds. 2011. El impacto histórico de la globalización en Argentina y Chile: empresas y empresarios. Buenos Aires: Temas Grupo Editorial

Khanna, Tarun, and Yishay Yafeh. 2007. "Business Groups in Emerging Markets: Paragons or Parasites?" Journal of Economic Literature 45(2): 331-372.

Lanza, Edison, and Gustavo Buquet. 2011. La televisión privada comercial en Uruguay. Caracterización de la concentración de la propiedad, las audiencias y la facturación. Montevideo: Friedrich Ebert Stiftung.

Leff, Nathaniel. 1978. "Industrial Organization and Entrepreneurship in the Developing Countries: The Economic Groups.” Economic Development and Cultural Change, 26(4): 661-75.

Olesker, Daniel. 2001. Crecimiento y exclusión. Nacimiento, consolidación y crisis del modelo de acumulación capitalista en Uruguay 1968-2000. Montevideo: Ediciones Trilce.

Peres, Wilson, ed. 1998. Grandes empresas y grupos industriales latinoamericanos. México: Siglo XXI Editores.

Rama, Martín. 1990. “Crecimiento y estancamiento económico en Uruguay”. In Trayectorias Divergentes. Comparación de un siglo de desarrollo económico latinamericano y escandinavo, edited by Magnus Blomstron and Patricio Miller, 115-44. Santiago de Chile: Cieplan- Hachete.

Reig Nicolás. 2013. "Efectos de la inversión extranjera directa sobre la inversión en Uruguay." Documento de Trabajo No. 04/13. Departamento de Economía. Facultad de Ciencias Sociales- 
Universidad de la República. Available in: https://www.colibri.udelar.edu.uy/jspui/bitstream/20.500.12008/2251/1/DT\%20E\%20201304.pdf.

Shaikh, Anwar. 2006. Valor, acumulación y crisis. Buenos Aires: Ediciones RyR.

Stolovich, Luís. 1989. Poder económico y empresas extranjeras en el Uruguay actual. Montevideo: Centro Uruguay Independiente.

Stolovich, Luís. 1994. Poder económico en el Mercosur. Montevideo: Centro Uruguay Independiente. Stolovich, Luis, and Juan Manuel Rodriguez. 1987. "Gobierno y empresarios: sus vínculos personales.” In ¿Hacia dónde va el Estado uruguayo?, edited by Gerónimo De Sierra, 163-201. Montevideo: Fundación de Cultura Universitaria- CIEDUR.

Stolovich, Luís, and Juan Manuel Rodriguez. 1988. Ranking de empresas. Montevideo: Consultora RyM. Unpublished material.

Stolovich, Luís; Juan Manuel Rodríguez, and Luís Bértola. 1987. El poder económico en el Uruguay actual. Montevideo: Centro Uruguay Independiente.

Trías, Vivian. 1961. Reforma agraria en el Uruguay. Montevideo: Ediciones El Sol.

Trías, Vivian. 1971. Imperialismo y rosca bancaria en el Uruguay. Montevideo: Banda Oriental

Viñales, Gustavo. 2019. Uruguay. Evolución del sistema tributario 1990-2018. Montevideo: Banda Oriental and La Ley Uruguay.

Williamson, Oliver. 1985. The Economic Institutions of Capitalism: Firms, Markets, Relational Contracting, New York: The Free Press.

Zurbriggen, Cristina. 2006. Estado, empresarios y redes rentistas durante el proceso sustitutivo de importaciones. Los condicionantes históricos de las reformas actuales, Montevideo: Editorial Banda Oriental.

This is an Open Access article distributed under the terms of the Creative Commons Attribution-Non-Commercial-No Derivatives License (http://creativecommons.org/licenses/by-nc-nd/4.0/), which permits non-comercial re-use and distribution, provided the original work is properly cited, and is not altered or transformed in any way. 